\title{
African heritage in a changing climate
}

\author{
Nick Brooks ${ }^{\mathrm{a}}$, Joanne Clarke ${ }^{\mathrm{b}}$, Grace Wambui Ngaruiya ${ }^{\mathrm{c}}$ and Elizabeth Edna Wangui ${ }^{\mathrm{d}}$ \\ ${ }^{a}$ Garama 3C Ltd, Sackville Place, Norwich, NR3 1JU, United Kingdom and Climate Research \\ Unit, School of Environmental Sciences, University of East Anglia, Norwich NR4 7TJ, United \\ Kingdom; 'Department of Art History and World Art Studies, University of East Anglia, \\ Norwich, NR4 7TJ, United Kingdom; 'Department of Plant Sciences, Kenyatta University, \\ P.O. Box 43844, 00100 Nairobi, Kenya; ${ }^{\mathrm{d} D e p a r t m e n t}$ of Geography, and Center for \\ International Studies, Ohio University, Athens, OH 45701, United States of America
}

CONTACT joanne.clarke@uea.ac.uk

\section{ARTICLE HISTORY}

Received 4 February 2020

Accepted 15 May 2020

\begin{abstract}
Climate change is a real and present threat to heritage across the world. In Europe and North America, research on the impacts of climate change on heritage, including how to mitigate against more frequent extreme weather events and how to implement efficient sustainable adaptation planning, are now key foci of heritage literature. In contrast, virtually nothing has been written about the impacts of climate change on heritage on the African continent, even though these will be significant in the coming decades. Heritage is essential for livelihoods, but also for the construction and reinforcement of identity and the psychological wellbeing of society. Here we consider the impacts of climate change on different (connected) forms of heritage in Africa, including archaeological, historical and living heritage. We situate the implications of climate change for African heritage in recent debates around climate justice, sustainability and social wellbeing. We conclude that without significant intervention some of Africa's most important heritage will be lost as a result of the direct and indirect impacts of climate change over the coming decades. Our intention is to draw attention to the need for research into the impacts of climate change on different forms of heritage in Africa and to highlight the possible deleterious effects these losses will have on society more generally. We view this paper as a first step in developing a research agenda that will have a practical application for the management of heritage in the face of climate change in Africa.
\end{abstract}

KEYWORDS Africa; heritage; climate change; sustainability; climate justice

RÉSUMÉ Le changement climatique est une menace réelle et présente pour le patrimoine à travers le monde. En Europe et en Amérique du Nord, la recherche sur les impacts du changement climatique sur le patrimoine, y compris la manière de lutter contre des événements météorologiques extrêmes plus fréquents et la manière de mettre en œuvre une planification efficace de l'adaptation durable, sont désormais des axes clés de la littérature sur le patrimoine. En revanche, pratiquement rien n'a été écrit sur les impacts du changement climatique sur le patrimoine sur le continent africain, même s'ils seront importants dans les prochaines décennies. Le patrimoine est essentiel pour les moyens de subsistance, mais aussi pour la construction et le renforcement de l'identité et le bien-être psychologique de la société. Ici, nous considérons les impacts du changement climatique sur différentes formes (connectées) de patrimoine en Afrique, y compris le patrimoine archéologique, historique et vivant. Nous situons les implications du changement climatique pour le patrimoine africain dans les débats récents sur la justice climatique, la durabilité et le bien-être social. Nous concluons que sans 
intervention significative, une partie du patrimoine le plus important de l'Afrique sera perdue en raison des impacts directs et indirects du changement climatique au cours des prochaines décennies. Notre intention est d'attirer l'attention sur la nécessité de recherches sur les impacts du changement climatique sur les différentes formes de patrimoine en Afrique et de mettre en évidence les effets délétères possibles que ces pertes auront sur la société en général. Nous considérons ce document comme une première étape dans l'élaboration d'un programme de recherche qui aura une application pratique pour la gestion du patrimoine face au changement climatique en Afrique.

\section{Introduction}

Heritage in Africa is facing multiple threats, including economic development, agricultural expansion, urbanisation, the direct and indirect effects of conflict, hydro-meteorological hazards, mineral and fossil fuel exploration, looting and illicit trade in cultural materials, the impacts of tourism, vandalism, low prioritisation and neglect (Anag et al. 2002; Brooks 2005; di Lernia 2005; Keenan 2005; Mitchell 2008; Cunliffe 2017; Lostal et al. 2017; Nicu 2017; Pavlova et al. 2017; Chirikure et al. 2017; Nhamo 2018). Climate change associated with anthropogenic global warming represents an additional and potentially profound threat to African heritage. Current climate and energy policies are likely to result in global warming of around $3{ }^{\circ} \mathrm{C}$ before 2100 relative to the pre-industrial period (UNEP 2019). Climate change is already exacerbating hydro-meteorological extremes including storms, heavy rainfall, floods, droughts and heat waves (O'Gorman 2012; Panthou et al. 2014; Skinner and Diffenbaugh 2014; Westra et al. 2014; Dong and Sutton 2015; Engelbrecht et al. 2015; Jolly et al. 2015; Kundzewicz et al. 2015; O'Gorman 2015; Donat et al. 2016; Papalexiou et al. 2018; Yin et al. 2018), but its impacts extend beyond intensification of these extremes. In the coming decades the world will face shifts in climatic and ecological zones and potentially profound changes in local and regional environments. Previous climatic reorganisations, even those associated with small changes in global average surface temperature, have resulted in large-scale landscape transformation (e.g. through desertification) and significant changes in the availability and distribution of key resources - principally water, plant and animal species - and productive land, with profound implications for human societies (Brooks 2006, 2010, 2013; Manning and Timpson 2014; Clarke et al. 2016). Global mean sea-level is expected to rise by up to $1 \mathrm{~m}$ by 2100 , with high-end estimates of over $2 \mathrm{~m}$ by this date and over $7 \mathrm{~m}$ by 2200 (Bamber et al. 2019).

It is becoming increasingly recognised that climate change and variability (http://www.wmo.int/pages/prog/wcp/ccl/faqs.php) have potentially serious implications for the historic environment. Yet heritage is unprepared for future climate change (Sabbioni et al. 2008) and there is a lack of research on how heritage management is responding to a changing climate, particularly with respect to the capacity of current management systems to prepare for and deal with its consequences (Phillips 2015: 119). Although an increasing body of literature is addressing the impacts of climate change on heritage globally, and in specific national contexts (e.g. Adams 2006/2007; Egloff 2008; Berenfeld 2008; Pearson 2008; Sabbioni et al. 2008; Kelman et al. 2011; Dželebdžić et al. 2013; Howard 2013; Daly 2014; Giesen et al. 2014; Harvey and Perry 2015; Perry 2015; Hall 2016; Howard et al. 2016; Fatorić and Seekamp 2017; Carmichael et al. 2018; Ezcurra and Rivera-Collazo 2018; Shirvani Dastgerdi et al. 2019), with very few exceptions (e.g. Colette et al. 2007; Adger et al. 2011; Viles and Cutler 2012; Reimann et al. 2018; UNESCO 2018; Esteves and Ballesteros 2019) the implications of climate change for heritage in Africa have received little explicit attention. Fatorić and Seekamp (2017: 234) record that only $1 \%$ of the climate change heritage literature is dedicated 
to the African continent, yet heritage is argued to be essential for social wellbeing (Adger et al. 2011). It provides communities with places of memory, ownership and belonging and is increasingly thought to offer recognition to under-represented populations (Rowlands and de Jong 2007: 16). Rowland and de Jong (2007: 18) further note that 'the failure to preserve and restore cultural heritage in Africa is equivalent of a failure in the preservation of cultural rights'. There is therefore an urgent need for those concerned with, and responsible for, the management of African heritage to consider the implications of climate change for how they undertake this task.

Following Chilton and Mason (2010), we define heritage in the African context as the full range of a society's inherited traditions, monuments, objects, places and culture, as well as the contemporary activities, knowledge, meanings, and behaviours that are drawn from them. Orthodox definitions of heritage have been shaped by the discipline of archaeology (Keitumetse 2016: 3), which does not take into account the palimpsest of interwoven, dynamic behaviours and belief systems that characterise African heritage. In fact, a great deal of heritage in Africa takes the form of biocultural (Bwasiri 2011; Manetsi 2011; Keitumetse 2016: 8; Ekblom et al. 2019; Lindholm and Ekblom 2019) and living heritage (Keitumetse 2016: 10). In order to protect such a diverse range of heritage, conservation measures would be better designed on a case-by-case basis, rather than by applying 'common decision-making frameworks' (Adger et al. 2011: 2) that do not take into consideration the intricate social, ideological and cosmological relationships inherent in African heritage. Chirikure et al. (2017: 1) argue that 'the universalism championed by directly transplanting Western ideas into Africa without considering the local situation has suffocated local knowledge systems, which have historically provided context-mediated and outcomes-based solutions to heritage conservation.' A case in point is UNESCO's separation of heritage into natural and cultural: 'natural' environments are culturally constructed and should be considered as such within African heritage management. Niger's Aïr and Ténéré Reserves are listed as natural heritage sites in the UNESCO World Heritage List (https://whc.unesco.org/en/list/573) but they are not natural landscapes but cultural landscapes that house some of the most spectacular rock art in the world, art that cannot be uncoupled from the topography and geology within which it resides. The single difference between these and contemporary rock art sites such as the Chongoni Rock Art Area in Malawi (https://whc.unesco.org/en/list/476) (Smith 2014), is time. The different classifications these sites are given inevitably result in different management plans.

In this paper we draw upon a number of case studies that highlight the importance of a holistic approach to heritage conservation in the face of climate change. We demonstrate that, unlike many other regions of the world, African heritage is predominantly an active resource (Chirikure et al. 2017: 4-5). Although some archaeological heritage is static, most African heritage is continuously 'being made'. The knowledge to build in adobe, to fish using traditional methods, to create rock art, to gather in sacred groves or to follow traditional pastoralist lifestyles represents a tiny sample of heritage at risk from climate change. One of the greatest changes happening across the African continent right now is the migration of young people into towns and cities in order to benefit from the opportunities that they afford. Although there are multiple and complex reasons for this trend, the peri-urban centres and makeshift 'towns' that house large numbers of people, mostly from rural communities, are the outcome of this demographic shift and are themselves extremely vulnerable to hazards associated with climate change and variability (Jarvie et al. 2015; Israel 2017). Peri-urban centres may not represent heritage in a conventional sense, but many of their inhabitants have brought with them knowledge of traditional lifeways that, because of shifting demographics, are becoming 
scarcer in the places where these 'urban-migrants' originated. Moreover, that loss is irreplaceable. Because these sets of knowledge are not required in the towns and cities to which people have migrated they are not maintained and passed on. This traditional knowledge 'drain' is one of the unseen contributors to heritage loss, as we highlight below. The next ten years will be crucial for Africa in addressing these complex issues of tradition versus modernity and the importance of traditional lifeways in the face of climate change: heritage must not be left off the agenda.

\section{Materials and methods}

In this paper we explore the potential implications of climate change for different forms of heritage in Africa, via a targeted, trans-disciplinary review of relevant literature. Using a method developed for systematic literature reviews in the social sciences, first described by Popay et al. (2004) and applied to heritage-climate change literature by Fatorić and Seekamp (2017: 229, Figure 1), we update and extend keyword searches in relevant electronic bibliographic databases, including African Journals Online, Google Scholar, JSTOR and Web of Science. Drawing on our combined expertise we analyse the literature and present representative case studies from North Africa, West Africa and East Africa that illustrate the severity of potential loss of heritage from different impacts of climate change. We recognise that we are not able to include the full range of heritage loss for all of the African continent and we acknowledge that some threats to heritage are becoming critical, for example sea-level rise in multiple locales across the continent (see Clarke et al. in prep). However, our case studies illustrate that climate change has already impacted African heritage and that it will pose an existential threat to it in the future. We then examine the wider consequences of these impacts, addressing the role of climate change adaptation in heritage management. Finally, we link threats to heritage with issues of 'climate justice' (Maus 2014; Okereke and Coventry 2016; Robinson and Shine 2018) and questions of responsibility for the preservation and management of cultural heritage, placing these issues in the wider context of the role of heritage in history, memory and identity (Coombes et al. 2014). We divide our results into two sections, one exploring the effects of sea-level rise and coastal erosion, the other considering climate change and variability. Climate variability refers to variations in mean climatic conditions and in the behaviour of extremes on timescales longer than those associated with individual weather events. Climate change refers to changes in mean climatic conditions and in variability that persist for extended periods, typically decades or longer (IPCC 2018).

\section{Results 1: sea-level rise and coastal erosion}

Traditional coastal economies are part of Africa's heritage, but local anthropogenic activity and climate change together have aggravated coastal erosion along parts of the African coast. A recent study by Vousdoukas et al. (2020: 260) estimates that by the end of the century the erosive trend for sandy shorelines in particular could result in coastline retreat of up to $240 \mathrm{~m}$ under worst case emissions scenarios (Representative Concentration Pathway [RCP] 8.5), while Kulp and Strauss (2019) conclude that significant parts of the African coastal zone will be inundated by 2100 under a plausible increase in global mean sea-level of over $2 \mathrm{~m}$ under moderate to high emissions pathways. By 2050, Guinea, The Gambia, Nigeria, Togo, Bénin, Congo, Tunisia, Tanzania (including Zanzibar) and the Comores will all be at significant threat of coastal erosion and sea-level rise (Kulp and Strauss 2019; Vousdoukas et al. 2020). Many African countries are particularly vulnerable to accelerated shoreline retreat, which will threaten the livelihoods of communities that populate coastal zones and may result in large scale relocation. Africa's coastal regions are densely populated. Urbanisation, construction, 
land management strategies and resource extraction have all contributed to rapidly changing coastlines (Goussard and Ducrocq 2014). The impacts that sea level rise and storm surges have already had, and will continue to have, on fragile ecosystems (coastal forests, mangroves, lagoons, river deltas, harbours) is now an international concern (https://www.ramsar.org).

\section{West Africa}

More than half of West Africa's total urban population is located in a coastal zone that amounts to only one twentieth of its land mass (Goussard and Ducrocq 2014: 10). Between Senegal and Nigeria the coastline is characterised by a wide range of habitats made more vulnerable to climate change by anthropogenic activity. Although there is some protection for unique environments such as the Banc d'Arguin National Park in Mauritania and the Senegal River Delta, both of which are listed Ramsar sites, other important coastal habitats, particularly in southwest African countries, which do not have their coastal zones protected by national and international recognitition, are at severe threat. Relict Guinean coastal forests have largely disappeared (Goussard and Ducrocq 2014: 15) and today practically no forest remains on the edge of the coastal zone, exacerbating coastal erosion. What remains of these fragile ecologies has been made more vulnerable to climate variability by increasing pressures associated with urbanisation, resource extraction and coastline alteration (Croitoru et al. 2019). The rich wetland and lagoon environments of Ghana, Togo, Bénin, and Nigeria are globally recognised as key for biodiversity, but a large proportion is still at threat from climate variability (storm surges) interacting with and mediated by climate change (sea-level rise) (Dossou and Glehouenou-Dossou 2007; Appeaning Addo et al. 2011; Owusu and Oteng-Ababio 2011; Appeaning Addo 2013; Croitoru et al. 2019).

Although considerable work has been done on coastal erosion in West Africa (for example, by the Nordic Development Fund and the World Bank), none of this work has considered heritage as a key element in the sustainability of these regions. As an example, half of Bénin's population (over three million inhabitants) is located in the city of Cotonou on the Gulf of Guinea (Dossou and Glehouenou-Dossou 2007). The coastal location is important to Cotonou's economy, but the coastal region is vulnerable to sea-level rise with potentially catastrophic impacts on the economy, the population and natural systems. Coastal fishing is a mainstay of Cotonou's economy, providing a livelihood for more than 15,000 people (those engaged in fishing and also associated jobs such as fish wholesaling and boat repairs) and any undermining of traditional fishing practices will lead to a loss of cultural diversity.

\section{East Africa}

Villages and towns associated with the historic Swahili Indian Ocean trading networks are almost all located on the coasts of Mozambique, mainland Tanzania, Kenya, the Comoro Islands, Zanzibar and Madagascar and all will suffer significant loss from sea-level rise and coastal erosion in the coming decades (Pollard 2009; 2012: 146; Breen et al. 2015; Clarke et $a l$. in prep). Unique heritage locations, including Ibo Island in the Quirimbas Archipelago in northern Mozambique (Berti 2020), Shanga and Pate islands in Kenya (Fleisher and Wynne Jones 2012), Pemba (Fleisher and LaViolette 2013) and the ruins of Kaole in Tanzania (Pollard 2009; Fleisher and LaViolette 2013), Mahilaka in Madagascar (Radimilahy and Crossland 2015) and Suakin in Sudan (Breen et al. 2015) are built on coral, sand or mud, all at an elevation of less than $10 \mathrm{~m}$. This combination of underlying geology and low elevation make these sites extremely susceptible to coastal erosion (Esteves and Ballesteros 2019; Vousdoukas et al. 2020). In addition, low-lying World Heritage Sites that are also densely populated, such as 
Lamu Old Town (https://whc.unesco.org/en/list/1055) and the Stone Town of Zanzibar (https://whc.unesco.org/en/list/173) are located in regions of the world predicted to be most severely impacted by shoreline retreat (Vousdoukas et al. 2020: 262, Figure 3).

\section{North Africa}

The Nile Delta and its coastal margins host some of the world's most significant built heritage. Without intervention, many ancient coastal sites will be lost in the next few decades (Parcak et al. 2017). The greatest contributing factor is relative sea-level rise from a combination of climate change and human intervention (Stanley and Clemente 2017). Increased eustatic (world) sea-level rise in combination with recent neotectonic lowering of the delta surface associated with substrate displacement, ongoing compaction of the Holocene sedimentary sequence and diminished sediment replenishment by the Nile River at the delta coast and its adjacent shelf (Stanley and Clemente 2017: 4) have all contributed to the extreme vulnerability of important heritage sites. It is expected that the rate of subsidence will increase with the completion of Ethiopia's Grand Renaissance Dam (GERD) (Zhang et al. 2015; Stanley and Clemente 2017: 4).

The problem is not confined to Egypt. Coastal margins elsewhere in North Africa are suffering the same cultural losses (Reimann et al. 2018). Figure 1 shows the site of Sabratha on the Libyan coast, which has already been critically affected by coastal erosion, sea level rise, subsidence and storm surges. These processes will be exacerbated by future sea-level rise. Reiman et al. (2018: Figures 3 and 5) show that both Sabratha and Leptis Magna are at high risk of flooding and coastal erosion in the coming decades.

\section{Results 2: climate change and variability}

Climate variability can affect both tangible and intangible heritage, principally through variations in seasonality and the behaviour of climate and weather extremes. Changes in seasonal conditions such as the timing or rainfall can affect livelihoods, while extremes in weather and climate can affect physical aspects of heritage and communities and populations who act as repositories of knowledge, skills and practice. Climate change can affect climate variability, for example resulting in more frequent, severe and protracted extremes. This can increase the risk of physical damage to tangible heritage. Long-term changes in mean climatic conditions and the behaviour of extremes can directly affect the viability of livelihoods and practices that embody aspects of intangible heritage, and can affect heritage indirectly through its effects on population behaviour and social organisation. Here we examine the effects of climate change and variability on tangible heritage in the form of rock art, intangible heritage in the form of pastoralism, and forms of heritage that blend the tangible and intangible, in the form of the management of sacred groves and adobe building traditions.

\section{Rock art}

The African continent boasts some of the world's most exceptional and important rock art, consisting of both paintings and engravings (Smith 2013). African rock art is vulnerable to accidental or deliberate damage from human activities, and to deterioration as a result of natural processes ('weathering'), which is already resulting in destruction in some parts of the continent (Meiklejohn et al. 2009; Mol and Viles 2010). Climate change may result in changes in weathering mechanisms and rates, and in the behaviour of periodic extremes that can damage or even destroy rock art. 


\section{Weathering, rock art and climate change}

Rock art is subject to a variety of weathering mechanisms, including very short-period climatic fluctuations. Weathering mechanisms depend strongly on the nature of the rock surface on which paintings or engravings are housed (Hall et al. 2012). These mechanisms include the following: cryoclasty, involving the freezing of water within the rock; moisture exchange between the atmosphere and rock surface and moisture movement within the rock; salt crystallisation; biotic processes including exfoliation through the actions of cyanobacteria; thermal shock resulting from rapid heating and cooling; and longer-duration thermal stress resulting from temperature gradients within the rock (Sperling and Cooke 1985; Büdel et al. 2004; Turkington and Paradise 2005; Hœrlé 2006; Meiklejohn et al. 2009). Clay-rich sandstones are particularly vulnerable to increases in relative humidity (Nara et al. 2011). Paintings are particularly vulnerable to weathering and are subject to specific weathering mechanism such as differential heating between different pigments, and between pigments and rock surfaces, due to their chemical and thermal properties (Figure 2). This can lead to stresses within rock paintings that drive erosion (Hœrlé 2006; Hall et al. 2007).

Soiling of stone surfaces involving the deposition of particulate matter can increase the absorption of radiant energy, raising the temperature of the stone and increasing weathering rates (Warke et al. 1996). Urbanisation and increased pollution (e.g. from vehicles) may result in increased atmospheric particulate loadings and particulate deposition on rock surfaces, exacerbating this phenomenon and accelerating the erosion of stone and rock surfaces with cultural value in the vicinity of growing urban centres. Aeolian deposition can also influence weathering processes through similar mechanisms (Meiklejohn et al. 2009).

Climate change may affect the weathering of rock surfaces, and therefore of rock art, via a number of mechanisms. Increases in temperature may enhance temperature-dependent chemical weathering processes such as silicate hydrolysis, with chemical weathering accelerating physical weathering through processes such as abrasion, and vice versa (White and Buss 2014). Higher temperatures may also result in stronger temperature gradients within rock paintings employing different pigments and between pigments and rock surfaces, amplifying thermal stresses. Any such effects are likely to be particularly pronounced in the Sahara, where near-surface warming over the period 1979-2012 was two to four times greater than the average level of warming in the tropics as a whole (Cook and Vizy 2015).

Thermal weathering may also be influenced by changes in cloud cover and atmospheric dust content. Reductions in cloud cover are projected over southern Africa under all warming scenarios, and over parts of North Africa and West Africa for warming above $2^{\circ} \mathrm{C}$, with greater reductions under higher warming (Collins et al. 2013). Atmospheric dust loading over the Sahel and Sahara is also likely to decline under future warming (Evan et al. 2016; Taylor et al. 2017). Reduced cloud cover and atmospheric dust concentrations will increase both diurnal temperature ranges and incident solar radiation on exposed rock surfaces, increasing rapid daytime heating and thermal stress and shock.

Changes in wind strength may influence weathering via abrasion. In the Sahara and the Sahel, projected reductions in winter Harmattan wind strength may be countered by increased wind strength associated with the passage of African Easterly Waves and associated convective storms in summer (Skinner and Diffenbaugh 2014; Cook and Vizy 2015). 
Climate change may also influence rock art via changes in microbial, plant and animal life at rock art sites. Biotic communities on rock surfaces are sensitive to changes in precipitation, atmospheric composition and particulate deposition and changes in these parameters may result in the rock biota switching from a bioprotective to a biodeteriogenic function, or vice versa (Viles and Cutler 2012). Shifts to more humid conditions in currently arid areas would be particularly problematic. For example, the abundant engravings of the Messak Settafet in Libya, located on sandstone surfaces in ephemeral and largely inactive water courses, currently host no biological growths (Figure 3), in contrast to sites in the Golden Gate Highlands in South Africa that host 'luxuriant growth of ... endolithic lichen ... [which] ... produces intense biodeterioration' (Viles and Cutler 2012: 2414). Projected shifts to more humid conditions in the central and eastern Sahel (Skinner and Diffenbaugh 2014; Dong and Sutton 2015) could impact significantly on biogenic influences on weathering, as well as on processes related to moisture exchange between the rock surfaces and the atmosphere, moisture movement within the rock, and salt crystallisation.

\section{Damage from enhanced episodic climate hazards}

Climate change has been associated with increases in rainfall intensity, surface runoff and flood risk (O'Gorman 2012; Panthou et al. 2014; Westra et al. 2014; Donat et al. 2015; Kundzewicz et al. 2015; O'Gorman 2015; Yin et al. 2018). These changes have the potential to affect rock art (and other heritage) sites through water and flood damage, particularly if the result is floods of historically unprecedented severity or floods becoming common in areas where they have previously been rare or absent. Some studies suggest a large increase in the frequency and intensity of extreme precipitation events in the Sahel (Klutse et al. 2018; Dosio et al. 2019; Kendon et al. 2019), regardless of whether or not the region shifts to a generally more humid regime (Skinner and Diffenbaugh 2014; Dong and Sutton 2015). This could dramatically increase the exposure of rock art (and other aspects of tangible heritage) to flash floods. Much of the rock art here and in the Sahara post-dates the desiccation of the middle to late Holocene (Smith 2013: 156) and would thus be at particular risk from a shift to a more humid regime.

Even where climate change does not result in an overall reduction in precipitation, increased evapotranspiration due to higher temperatures, more frequent and protracted heat extremes (Engelbrecht et al. 2015; Papalexiou et al. 2017), longer periods between rainfall events and intensification of droughts (Panthou et al. 2014) will increase the risk of wildfires (Engelbrecht et al. 2015; Jolly et al. 2015). In the event of a shift to more humid conditions in areas such as the Sahel, increased vegetation cover could further increase the risk of large-scale wildfires during episodes of extreme heat and drought, by providing additional fuel mass, with risks further amplified by any increase in wind strength during fire seasons (Park Williams et al. 2019). Lehsten et al. (2008) describe how carbon emissions from African wildfires are related to precipitation and available litter/fuel mass, while Forsyth et al. (2010) show that fire risk has increased in South Africa in recent decades. Tadross et al. (2011) anticipate further increases in fire intensity, severity and extent in southern Africa as a consequence of climate change. Liu et al. (2010) use climate model output to identify areas in which wildfire potential is projected to increase, including in southern Africa. There is less information on potential changes in fire risk in other African regions, although Engelbrecht et al. (2015) conclude that the frequency of high fire-danger days is likely to increase in the savanna regions of southern Africa and the Sahel.

While future fire risks to African rock art are difficult to assess and remain somewhat speculative, they should not be dismissed. The United States Bureau of Land Management lists 
some impacts of wildfires on rock art (Winthrop, no date). These include soot smudging and smoke discoloration, which can obscure images, heat-induced changes in organic paints, and damage to rock varnish that may destroy the potential for dating. Above $300^{\circ} \mathrm{C}$, sandstone undergoes oxidation, while at $700^{\circ} \mathrm{C}$ it spalls and fractures, resulting in exfoliation and degradation. Wildfires can also have other, unanticipated impacts on rock art. Rock art at Balloon Cave in Carnarvon National Park, Queensland, Australia was destroyed when a plastic walkway exploded during the 2018 wildfires (Taçon 2019).

\section{Sacred groves}

Sacred groves are traditionally protected forests that are significant in heritage terms because they are instances where environmental stewardship and spiritualism interconnect in an historical setting. Often comprising rare tree species, stones, water, mountains and caves, sacred groves are dynamic and meaningful biocultural sites for historical negotiation (Ogundiran and Ogunfolakan 2017). In Sub-Saharan Africa they generally include shrines for worship, while in the Maghreb holy forests that are protected from clearing surround the tombs of Muslim saints (Deil et al. 2005). Regular maintenance of the sculptures and monuments contained within these traditionally protected forests is intrinsically tied into the religious practices performed within them. These activities are fundamental for bringing together the community, understanding traditional construction resources, integrating new durable resources into cultural heritage management, and documenting traditional rituals.

Sacred groves serve important ecological and socio-cultural functions by preserving virgin forests that act as important refuges for rare and useful local biodiversity (Nganso et al. 2012). However, according to the United Nations Food and Agriculture Organisation (FAO) (2017), climate change impacts threaten African forests with accelerated loss of plant biodiversity, increased risk of bush fires and ecosystem shifts (for example, forest to woodlands, or woodlands to grasslands). In addition, Claeys et al. (2019) demonstrate that climate change will sharply intensify Central African forest dynamics, with increases in growth, mortality and recruitment, leading to changes in forest structure and composition, namely a natural thinning effect with fewer but larger trees, but increases in the relative proportion of pioneers to the detriment of shade-bearers. A key impact will be a continuing decline in plant biodiversity for medicinal, social and religious purposes (Nganso et al. 2012). Any significant change in either the habitat (through impacts of climate change) or the community (e.g. through migration and conflict) has the potential to result in a decline in, or cessation of, social activities associated with traditionally protected forests. African traditions and practices that are passed on orally are particularly susceptible, with any loss here a potentially irreversible weakening of a community's cultural heritage.

As heritage resources, traditionally protected forests can be sustainably packaged for heritage tourism and community development, while also acting as places of empowerment and community cohesion. For example, Nigeria's Osun-Osogbo Grove, a UNESCO World Heritage Site (https://whc.unesco.org/en/list/1118) hosts a widely attended annual festival, with around 150,000 Osun worshippers, spectators and tourists visiting it in 2012 (Woosnam et al. 2016). Events of this kind bring in revenue that facilitates conservation of the forest.

Legal recognition of sacred forests is an important step in providing communities with a role in the management their own heritage resources, while also enabling the potential for preservation of biological diversity and ecological systems (Parthasarathy and Naveen Babu 2019). Sacred natural sites also offer opportunities for building landscape connectivity 
networks because they form important refugia for biodiversity (Hailemariam 2019). An example is the sustainable use and conservation of medicinal plants, especially sacred trees that have medicinal value. This can be achieved through secrecy, plant protection at burial sites, the sacredness of the plants themselves and domestication (Msuya and Kideghesho 2009). Since heritage sites are situated in specific landscapes that contribute to their Outstanding Universal Value, well developed site management plans may provide an opportunity to promote climate resilience through careful preservation and conservation of their ecosystems (O’Brien et al. 2015).

\section{Pastoralism, adaptation and the impact on heritage}

Pastoralism, characterised by a reliance on livestock and the use of grasslands as pasture (Wangui 2018), provides a livelihood for an estimated 268 million Africans (FAO 2018). The result of indigenous innovation in the prehistoric Sahara that subsequently spread to SubSaharan Africa (Sawchuk et al. 2018), pastoralism represents a link with the deep past and is fundamentally rooted in resilience and adaptation to rapid and severe climate change of the kind likely to be experienced in some African regions over the coming decades. Pastoral livelihoods, traditions and knowledge therefore represent a key aspect of intangible heritage in Africa that is highly relevant in the context of adaptation to climate change.

Pastoralism is defined by investment in herding labour and capital and by a worldview and identity centred around herding (Bollig and Schnegg 2013). It is typically carried out in drylands, where pastoralists need to navigate a high degree of climatic variability alongside constantly shifting economic and political contexts that constrain their pastoral activities. National priorities are often in conflict with the needs and priorities of African pastoralist communities, with many African governments having promoted crop farming and wildlife conservation at the expense of pastoralism. This is often linked with efforts to 'modernise' pastoralism, rooted in narratives of progress propagated during the colonial period, which prioritise pastoralist sedentarisation over mobility (Lane 1997; Schneider 2006; Beyenne and Korf 2008; Davies 2008; African Union 2013; Oba 2014; Korf et al. 2015). Pastoralists thus need to combine adaptation to climate change with adaptation to changing institutional and policy contexts, even as the latter undermine their 'adaptive capacity' to achieve the former, for example by restricting their mobility and their access to historical dry-period grazing areas.

Today, many pastoralists argue that their livelihood can only survive if it is combined with crop farming (Wangui 2014; Kavana et al. 2017). A shift to more crop farming transforms the landscape from one dominated by pasture to one dominated by a mosaic of farms and pasture (Benjaminsen 2016; Greiner 2016) (Figure 4). This transformation reduces the importance of pasture as a currency of reciprocity between pastoralist groups and hence changes existing social relations, while creating opportunities for new forms of reciprocity that might also enhance pastoralists' capacity to adapt to changes in climate and non-climatic factors (Wangui and Smucker 2017).

More fundamentally, such landscape transformation has implications for memory, culture and identity. A landscape is not simply a collection of ecological patches, but rather 'the reference system in which individual consciousness of the world and social identities are anchored' (Tilley 1994: 40). People ascribe meanings to landscapes based on their experiences, memory and the uses they impose on the landscape (Stewart and Strathern (2003: 3). Pastoralist adaptation involving sedentarisation and the adoption of farming thus has the potential to erode and erase cultural heritage founded on long-standing pastoral practices, worldviews and 
identities associated with mobility. This mobility is the result of complex decisions based on an intimate knowledge of local and regional ecologies, as well as existing social relations with other pastoral communities, that may be 'the result of cumulative experiences over generations' (Oba 2014: 53).

Pastoralists rely on mobility to utilise landscapes ridden with climatic uncertainty. Abundant archaeological evidence indicates that pastoralism in Africa originated and evolved as a response to increasingly marginal and variable climatic conditions in the prehistoric Sahara, as northern Africa transitioned to aridity (Smith 1992; di Lernia 2006; Jousse 2006). Saharan pastoralism evolved over many millennia, but waves of pastoral expansion coincided with periods of rapid and severe climatic and environmental change, notably in the fifth and fourth millennia BC, a period that represents the last episode of global climatic reorganisation (Sivili et al. 2002; di Lernia 2006; Brooks 2010). African pastoralism is thus fundamentally rooted in adaptation to profound climatic shifts of a kind likely to be experienced in many African regions as climate change accelerates over the course of the twenty-first century and beyond. While the current emphasis is on transitions from herding to farming, this process might be reversed in some locations where climate change is likely to make crop farming less viable. In these contexts, mobile pastoralism may represent a more appropriate economic strategy under new climatic and environmental conditions (Jones and Thornton 2009). Contrary to certain influential narratives, pastoralists are neither adherents to a primitive, archaic way of life that is no longer appropriate, nor are they necessarily among the groups most vulnerable to climate change. Rather, they are holders of knowledge that may become more relevant as climate change progresses. Where they are highly vulnerable to climate change, this is very often the result of policies that are hostile to their way of life, constrain their options, and limit their mobility and capacity to practice their livelihood strategies effectively.

While pastoral systems have developed to be resilient and adaptable in the face climatic variability and uncertainty (Roe et al. 1998; Krätli et al. 2013) they are challenged by climatic departures from historical norms and there are also absolute blimits to pastoral adaptation. Indigenous forecasts may break down as climate change alters the behaviour of droughts, and the past may cease to be a useful analogue for the future (Oba 2014; Kagunyu et al. 2016; Tamou et al. 2018). Very severe and protracted droughts can result in extended migration, the breakdown of social relations, a reconfiguration of identities around new activities such as farming and fishing and disruption to social and political institutions, resulting in a collapse of adaptive strategies (Zewde 1976; Herring 1979; Brown 1989; Caviedes 2001; Oba 2014).

The preservation of pastoralist heritage therefore requires that pastoralist identities, knowledge systems and livelihoods are recognised, valued and supported. Narratives of pastoralists as highly vulnerable to climate change need to be challenged, the resilience and adaptive capacity inherent in pastoral systems recognised. This might be aided by a greater awareness of African pastoralism's deep history and its roots in past adaptation to rapid and severe climate change. Preserving pastoral heritage requires policies that enable pastoralism to continue to evolve by blending traditional and novel practices and arrangements in order to navigate the double exposure of climate change and rapid socio-economic change. The integration of scientific, indigenous and other knowledge via a process of co-production involving pastoralists and other (e.g. national and international) actors has the potential to improve current adaptive responses by creating opportunities for the integration of local autonomous adaptation with planned adaptation (Mahoo et al. 2015; Jost et al. 2016; Ngaruiya and Muithui 2016; Reyes-Garia et al. 2016; Mashizha et al. 2017). More prosaically, adaptive capacity within pastoral systems 
can be maintained through measures such as the preservation of indigenous livestock breeds and associated genetic diversity (Figure 5).

\section{Adobe building traditions}

Arguably one of the most iconic forms of African heritage at risk from climate change is traditional adobe (mud brick) architecture, including the technology to build it and the knowledge systems and semiotics embedded within it (Birabi and Nawangwe 2008). Although temperature differentials and erratic precipitation regimes have a direct impact on adobe buildings, other multiple, interlinked, and often indirect factors mediated by a changing climate are already undermining traditional adobe building methods (Joy 2007). Yet, building in adobe is one of the most sustainable forms of architecture in Africa (Ejiga et al. 2012) and could be implemented in more arid regions as a building method in expanding peri-urban areas particularly vulnerable to climate shocks (Figure 6).

Birabi and Nawangwe (2008: 105) note that African adobe building practices and what they term the semiotics (the visual language) embedded in many traditions, have declined 'in part because the conservation of earthen architecture has been sluggish'. Magnificent examples of these styles can be found along the former imperial trade routes between East and West Africa at Tiebélé between Burkina Faso and Ghana, at the ancient desert town of Walata in Mauritania and at Akan in Ghana. Even the arrangement of the toron spikes used for scaffolding during the yearly resurfacing of the Great Mosque at Djenné in Mali (Figure 7) represents a visual language based within both technology and process (Joy 2007; Briabi and Nawangwe 2008). However, while the whole of Djenné's Old Town is a World Heritage site, the technological knowledge, rituals and social structures that are part of the yearly renewal of many earthen buildings in the city are being eroded by multiple, complex, interlinked social and environmental factors (Joy 2007, 2016). The attrition of artisanal craft skills has much to do with changing cultural tastes and technological 'advances' - globalisation, for example, has had a profound impact on traditional building methods by driving aspiration for, and imitation of, Western models of dwelling. However, these processes are also exacerbated by climate change. Djenné's locatation in Mali's Inland Niger Delta and high inter-annual climatic variability, coupled with the unpredictability of the annual Niger flood regime, force fishing, agriculture and pastoral systems here to be highly adaptive to stress (McIntosh 1995: 5). This impacts on economic security. Changes in agricultural practices caused by an increasingly unpredictable climatic regime have impacted deleteriously on traditional building methods, specifically contributing to the mud bricks used today being inferior in quality and durability. A reduction in rainfall and fish stocks has also degraded the quality of the mud used (Figure 8) as this requires calcified fish bones to make it resilient to extremes of climate (Joy 2007: 153). Additionally, climate variability has contributed to crop failures, leading to reductions in income such that local residents now find it difficult to afford the annual upkeep of their houses using traditional methods, because good quality materials have become too expensive and instead choose to use cheaper materials to repair their houses. The situation is complicated by UNESCO's mandate that restricts the use of updated repair technologies, placing a cost burden on owners. In some cases, fired clay tiles fixed with cement have been used to render the walls of mud buildings (Figure 9), something that is radically changing the town's appearance (Joy 2007: 154) and undermining the mud skeletons of its buildings.

Climate change is not the sole driver of heritage loss at Djenné, but it is a 'threat multiplier' (Causevic 2017). Increasingly, the risk to heritage from other factors is being amplified by climate variability and change. The increasing unpredictability of the Inland Niger Delta 
inundation is having unforeseen impacts on aspects of society that are more vulnerable to change. In the case of Djenné, heritage is very much at the centre of these unforeseen impacts.

\section{Earthen buildings, sustainability and climate change adaptation}

The irony of the Djenné case study is that buildings and construction account for over onethird of global final energy use, and nearly $40 \%$ of energy-related $\mathrm{CO}_{2}$ emissions when upstream power generation is included (Global Alliance for Buildings and Construction 2019). Due to increases in urban population and attendant residential pressures, energy consumption from buildings is projected to rise in buildings, especially in fast growing countries (Iwuagwu and Azubuine 2015: 50). A typical traditional building of earth emits fewer greenhouse gases than its 'modern' counterpart, consumes less energy and maintains a high level of internal thermal comfort, regardless of prevailing solar radiation outside (Iwuagwu and Azubuine 2015: $50)$.

A demonstration of the thermal environment in traditional earthen buildings can be found in a study of the old and new architecture of Ghadames in Libya (Ahmad et al. 1985). Traditional buildings here are constructed from a combination of clay and organic matter, with gypsum plaster used on internal walls and palm trunks for roofing. Dwellings are surrounded by adjacent houses on three sides with the remaining side facing the street, which is usually covered. Houses and streets are designed to create spaces that encourage air flow, and most of the dwelling is close to the ground. Kitchens are situated on roofs so that heat escapes directly to the atmosphere and does not warm the building. Roofs are designed to protect the houses from sun, but to allow breezes into houses at night.

In contrast, the modern settlement of Ghadames consists of one- and two-storey houses generally detached from their neighbours and constructed from conventional modern materials. Ahmad et al. (1985) recorded the internal temperature of traditional and modern houses in summer, when ambient air temperature was $20-40^{\circ} \mathrm{C}$, with an average of $31^{\circ} \mathrm{C}$. They report that the temperature in the modern dwelling ranged between $34^{\circ} \mathrm{C}$ and $39^{\circ} \mathrm{C}$, while that in the traditional dwelling remained constant at $28^{\circ} \mathrm{C}$. A further study comparing experiences of old and new dwellings in Ghadames concluded that people had an overall impression of higher standards of thermal comfort in old buildings compared to new ones (Ealiwa et al. 2001).

The need for adaptation to more frequent and extreme high temperatures, coupled with the potential problems of meeting increased demands for power as a result of greater use of air conditioning, means that a greater focus on passive cooling in building design is highly desirable. The incorporation of elements of traditional design into new buildings and settlements, and the preservation of knowledge and skills associated with traditional earthen building construction, can make a vital contribution to both adaptation and sustainability (Ejiga et al. 2012). Using traditional construction materials and methods would also reduce demand for cement, the production of which is a significant contributor to global emissions (Bignozzi 2011), while an increased emphasis on traditional construction could also align with cultureand heritage-focused tourism, contributing to economic development.

Traditional earthen buildings represent a unique aspect of cultural heritage in Africa and preservation of all aspects of this heritage might be justified on these grounds alone. However, earthen buildings also constitute a unique sustainable architecture that can contribute to both climate change adaptation and mitigation (Diop 2018). A combination of linked economic and environmental factors means that the knowledge, expertise and social-cultural practices and 
ceremonies that accompany building and renewal of earthen architecture are being lost across the continent (Joy 2007; Brimblecombe et al. 2011; Diop 2018). Urgent efforts to reverse this trend are required on multiple grounds.

\section{Climate justice and sustainable heritage for Africa}

Climate change poses a variety of direct and indirect threats to heritage in Africa and interacts with other factors to act as a threat multiplier. Its impacts raise questions of 'climate justice', a concept that recognises that those least responsible for anthropogenic climate change are often those most affected by its impacts, possess the least capacity to adapt and have the weakest voices in global climate change negotiations and discussions (Füssel 2010; Schlosberg and Collins 2014; Martinez-Alier et al. 2016). This 'asymmetry between responsibility/capability and vulnerability is considered unjust based on many intuitive as well as formalized concepts of justice, including the 'no harm' principle and the "polluter pays" principle' (Füssel 2010: 598).

Emerging within the environmental justice movement (Martinez-Alier et al. 2016), climate justice concerns itself predominantly with local impacts and experience, inequitable vulnerabilities and the necessity for community voice and sovereignty (Schlosberg and Collins 2014: 359). A disconnect that has particular relevance for climate justice in its relationship to heritage in Africa is that between the role of 'élite' non-governmental organisations, such as UNESCO, and grassroots movements. European colonisation Africa had profound repercussions for the stewardship of African heritage. Chirikure et al. (2017: 3) remind us that pre-colonial systems of heritage custodianship were managed at a local scale. The sacred groves of Nigeria, the masonic systems of Djenné and the preservation of standing monumental sites like Great Zimbabwe are all examples of heritage that has been managed for hundreds of years by indigenous communities (Chirikure et al. 2017: 5). Breen (2007), Ndoro (2015) and Joy (2016) tell us that heritage sustainability is contingent upon local custodianship, while Adger et al. (2011: 2), argue that 'highlighting the risks climate change poses to place and identity poses a challenge to notions of fairness in adaptation'. Heritage contributes to our understanding of who we are, but more importantly, to who we want to become. Without heritage, our connection to places, to the past and to the future can become untethered; this can have a long-term deleterious impact on social identity. The construction, maintenance and reinforcement of identity has been designated a human right under the United Nations' Sustainable Development Goals. Loss of heritage due to climate change into the next decades, and the potential associated erosion of cultural identities, needs to be included in the obligations of those countries and individuals with greatest responsibility/capability.

\section{Discussion}

As this paper has illustrated, the impacts of climate change for African heritage are intrinsically linked to the concepts of climate justice, sustainability and social wellbeing. In the arena of heritage, it is not simply a case of disproportionate exposure and impacts affecting the people and places least responsible for climate change. Climate justice also relates to people's ability to respond and adapt to climate change, how this ability affects and is affected by heritage and how it is mediated by external actors and élite interests. Not only is adaptive capacity deployed to preserve heritage, but it is also influenced by it. External interests create legal, institutional and policy contexts that shape and constrain action, and which often undermine the very adaptive capacity inherent in people's heritage. Pastoralism provides an exemplar of this paradox since it encompasses a suite of strategies that have evolved to provide reliable 
livelihoods in the face of high climatic variability and uncertainty (Roe et al. 1998). However, pastoralists' abilities to deploy these strategies have been heavily constrained by national governments that have sought to limit their mobility (Bloch and Foltz 1999). These governments have often characterised pastoralists as both regressive and highly vulnerable to climate change, drawing on narratives of progress and modernity imported to the continent during the colonial period (e.g. Schneider 2006; Beyene and Korf 2008) and linkages between pastoralism and desertification that do not stand up to scrutiny (Turner 1993; Brooks 2004). While pastoralists are vulnerable to climate change, much of this vulnerability is a result of development policies that undermine and erode the adaptive capacity inherent in pastoral systems.

The architectural preservation criteria established by UNESCO in Djenné represent a further set of constraints on local adaptation, this time by an 'élite' international non-governmental organisation. UNESCO requires local guilds to maintain brickmaking techniques that are increasingly impractical as a result of climate change impacts on mud composition, creating an institutional barrier to the deployment of adaptations that these guilds might otherwise adopt in order to respond to climatic and environmental change. This is contrary to increasingly widely recognised principles based on the creation of enabling environments for locally owned adaptation and the co-production of knowledge and solutions that are strongly driven by the beneficiaries or users of outputs from adaptation interventions (Ebi and del Barrio 2017; Wamsler 2017; Djenontin and Meadow 2018; Harvey et al. 2018; Ika and Donnelly 2018).

Khalil et al. (2018: 64) state that 'addressing climate change-induced heat stress in poor and informal areas becomes essential as an integrated part of environmental justice.' This observation is also relevant in relation to the apparent declines in thermal comfort associated with nationally mediated transitions from traditional to modern urban environments as described above for Ghadames. More generally, preserving intangible heritage that allows more accessible, sustainable and contextually appropriate building practices to be preserved and deployed as part of the adaptation process, perhaps blended with modern technologies such as renewables in using innovative hybrid approaches has the potential to help address issues climate justice.

The above examples emphasise the importance of institutional contexts and governance in adaptation and heritage preservation, and the complex, multi-scale nature of adaptation when it comes to managing cultural heritage. They also reflect the profound repercussions of colonialist policies, imported ideologies and multilateral approaches for the stewardship of African heritage.

The importance of heritage for healthy, sustainable and adaptable societies cannot be underestimated (Ndoro 2015). Loss of heritage will have a profound impact on societies in the twenty-first century if stringent measures to mitigate climate change are not implemented now at a global level. The extent of that loss is unknowable, but it is predicted that climate change will lead to significant social and economic changes and that these changes will, in turn, inevitably have lasting impacts on heritage. Heritage is often viewed through the lens of what can be seen - for example, disappearing coastlines with their famous archaeological sites but Africa's unseen heritage is just as important to preserve, and arguably more vulnerable to a changing climate. Ways of life that include songs, myths, stories, performances, ceremonies, traditional knowledge and subsistence practices are already under threat from economic development, urbanisation and conflict. In the coming decades climate change will exacerbate all of these threats. Recognising climate change as a significant threat multiplier to heritage in 
Africa is the first step in preserving heritage and allowing intangible heritage to evolve and adapt. Critically, this heritage itself may offer lessons and resources for adapting to climate change.

The significance of heritage is clear and there is an urgent need for heritage to be included in climate change discourses. African heritage is under threat from climate change, as the case studies we have presented demonstrate. The loss of heritage may not be felt immediately, but incremental loss, over time, could mean that we sleepwalk into a world where all kinds of valuable - indeed critical - heritage no longer exist.

\section{Acknowledgements}

The authors would like to thank the anonymous reviewers for their suggestions that have contributed to a significantly improved version of this paper. We would also like to thank Professor Anne Haour for providing early input to the West Africa and East Africa sections but acknowledge that any errors or omissions are wholly the responsibility of the authors. Thanks also go to Professor Haour for providing a French translation of our abstract. Dr Louise Rayne, Dr Bijan Rouhani and Professor David Mattingly of the EAMENA Project kindly gave us access to the EAMENA database and permission to reproduce images of Djenné was generously given by Erika Alatalo.

\section{Notes on contributors}

Nick Brooks is a Visiting Research Fellow in the Climatic Research Unit at the University of East Anglia, and Director of Garama 3C Ltd, a small firm specialising in climate change and international development. He is a specialist in climate change adaptation and has researched and published on adaptation to rapid and severe climate change in the archaeological record.

Joanne Clarke is Senior Lecturer in the Department of Art History and World Art Studies at the University of East Anglia. She researches the archaeology of marginal environments. She is a contributing author to the heritage section of the Africa chapter for the upcoming IPCC Sixth Assessment Report (AR6).

Grace W. Ngaruiya is Head of Ecology and Conservation Biology and Lecturer in the Department of Plant Sciences, Kenyatta University in Kenya. She is also a lead author in the upcoming IPCC Sixth Assessment Report (ARO) where her team is examining the relationship between climate change and Africa's heritage.

Elizabeth Edna Wangui is Director of Global Studies and Associate Professor of Geography at Ohio University, Athens, Ohio. Her research examines the gendered dimensions of rural development and rural livelihood change, environmental conservation and local knowledge and climate change adaptation. She has worked among pastoralists in East Africa for most of her career. Her current research examines the gendered dynamics of land restoration in a watershed-based payment for ecosystems services project in Kenya.

\section{References}

Adams, J. 2006/2007. "Global climate change: every cultural site at risk?" Heritage at Risk 2006/2007: 194-195. 
Adamson, G.C., Hannaford, M.J. and Rohland, E.J. 2018. "Re-thinking the present: the role of a historical focus in climate change adaptation research." Global Environmental Change 48: 195-205.

Adger, W.N. 2010. "Climate change, human well-being and insecurity." New Political Economy 15: 275-292.

Adger, W.N., Barnett, J., Chapin, F.S. and Ellemor, H. 2011. "This must be the place: underrepresentation of identity and meaning in climate change decision-making." Global Environmental Politics 11: 1-25.

African Union, 2013. Policy Framework for Pastoralism in Africa: Securing, Protecting and Improving the Lives, Livelihoods and Rights of Pastoralist Communities. Addis Ababa: African Union Department of Rural Economy and Agriculture.

Ahmad, Y. 2006. "The scope and definitions of heritage: from tangible to intangible." International Journal of Heritage Studies 12: 292-300.

Ahmad, I., Khetrish, E. and Abughres, S.M. 1985. "Thermal analysis of the architecture of old and new houses at Ghadames." Building and Environment 20: 39-42.

Anag, G., Cremaschi, M., de Lernia, S. and Liverani, M. 2002. "Environment, archaeology, and oil: the Messak Settafet Rescue Operation (Libyan Sahara). African Archaeological Review 19: 67-73.

Appeaning Addo, K.A. 2013. "Assessing coastal vulnerability index to climate change: the case of Accra-Ghana.” Journal of Coastal Research 65: 1892-1897.

Appeaning Addo, K.A., Larbi, L., Amisigo, B. and Ofori-Danson, P.K. 2011. "Impacts of coastal inundation due to climate change in a cluster of urban coastal communities in Ghana, West Africa." Remote Sensing 3: 2029-2050.

Arnell, N.W., Lowe, J.A., Challinor, A.J. and Osborn, T.J. 2019. "Global and regional impacts of climate change at different levels of global temperature increase." Climatic Change 155: 377-391.

Bamber, J.L., Oppenheimer, M., Kopp, R.E. Aspinall, W.P. and Cooke, R.M. 2019. "Ice sheet contributions to future sea-level rise from structured expert judgment." Proceedings of the National Academy of Sciences of the United States of America 116: 11195-11200.

Benjaminsen, T.A. 2016. "Water, labour and politics: land-use dynamics along the Niger River in Mali." In A History of Water: Series III, Volume 3: Water and Food, edited by Terje Tvedt and Terje Oestigaard, 398-417. London: I.B. Tauris

Berenfeld, M.L. 2008. "Climate change and cultural heritage: local evidence, global responses." The George Wright Forum 25: 66-82.

Berti, M. 2020. "Ibo Island in the Quirimbas Archipelago. An architectural heritage within a natural heritage." Conservation Science in Cultural Heritage 19: 251-266. 
Bewley, R., Wilson, A.I., Kennedy, D., Mattingly, D.J., Banks, R., Bishop, M., Bradbury, J., Cunliffe, E., Fradley, M., Jennings, R., Mason, R., Rayne, L., Sterry, M., Sheldrick, N. and Zerbini, A. 2016. "Endangered archaeology in the Middle East and North Africa: introducing the EAMENA Project." In Keep the Revolution Going: Proceedings of the 43rd Annual Conference on Computer Applications and Quantitative Methods in Archaeology CAA2015, edited by S. Campana, R. Scopigno, G. Carpentiero and M. Cirillo, 919-932. Oxford: Archaeopress.

Beyene, F. and Korf, B. 2008. Unmaking the Commons: Collective Action, Property Rights and Resource Appropriation Among (agro-) Pastoralists in Eastern Ethiopia (No. 88). CAPRi Working Paper. Washington DC: International Food Policy Research Institute.

Bignozzi, M.C. 2011. "Sustainable cements for green buildings construction." Procedia Engineering 21: 915-921.

Birabi, A.K. and Nawangwe, B. 2008. "Mitigating threats to local knowledge embedded in earthen architecture: the case of preserving African architectural semiotics." In Terra 2008: The 10th International Conference on the Study and Conservation of Earthen Architectural Heritage, edited by L. Rainer, A.B. Rivera and D. Gandreau, 104-108. Los Angeles: Getty Publications.

Bloch, P.C. and Foltz, J.D. 1999. Recent tenure reforms in the Sahel: Assessment and suggestions for redirection. Madison, WI: Land Tenure Center, Broadening Access and Strengthening Input Market Systems [BASIS].

Bollig, M. and Schnegg, M. 2013. "Introduction: specialization and diversification among African pastoral societies." In Pastoralism in Africa: Past, Present and Future, edited by M.Bollig, M. Schnegg and H.-P. Wotzka, 1-30. New York: Berghahn Books.

Breen, C. 2007. "Advocacy, international development and World Heritage Sites in subSaharan Africa." World Archaeology 39: 355-370.

Breen, C. Rhodes, D. and Forsythe, W. 2015. "The Suakin dilemma: conservation and heritage management in eastern Sudan." Conservation and Management of Archaeological Sites 17: $109-121$.

Brimblecombe, P., Bonazza, A., Brooks, N., Sampedro, G., Harris, I. and Sabbioni, C. 2011. "Impact of climate change on earthen buildings." In Terra 2008: The 10th International Conference on the Study and Conservation of Earthen Architectural Heritage, edited by L. Rainer, A.B. Rivera and D. Gandreau, 278-282. Los Angeles: Getty Publications.

Brooks, N. 2004. Drought in the African Sahel: Long term perspectives and future prospects. Tyndall Centre Working Paper 37. University of East Anglia, Norwich, UK.

Brooks, N. 2005. "Cultural heritage and conflict: the threatened archaeology of Western Sahara." Journal of North African Studies 10: 413-439.

Brooks, N. 2006. "Cultural responses to aridity in the Middle Holocene and increased social complexity." Quaternary International 151: 29-49. 
Brooks, N. 2010. "Human responses to climatically-driven landscape change and resource scarcity: learning from the past and planning for the future." In Landscapes and Societies, edited by I.P. Martini and W. Chesworth, 43-66. Dordrecht: Springer.

Brooks, N. 2013. "Beyond collapse: climate change and causality during the middle Holocene climatic transition, 6400-5000 years before present." Geografisk Tidsskrift-Danish Journal of Geography 112: 93-104.

Brown, M. 1989. Where Giants Trod: The Saga of Kenya's Desert Lake. London: Quiller Press.

Büdel, B., Weber, B., Kühl, M., Pfanz, H., Sültemeyer, D. and Wessels, D. 2004. "Reshaping of sandstone surfaces by cryptoendolithic cyanobacteria: bioalkalization causes chemical weathering in arid landscapes." Geobiology 2: 261-268.

Bwasiri, E.J. 2011. "The implications of the management of indigenous living heritage: the case study of the Mongomi wa kolo rock paintings World Heritage Site, Central Tanzania." South African Archaeological Bulletin 66: 60-66.

Cai, Y., Lenton, T.M., and Lontzek, T.S. 2016. "Risk of multiple interacting tipping points should encourage rapid $\mathrm{CO}_{2}$ emission reduction." Nature Climate Change 6: 520-525.

Carmichael, B., Wilson, G., Namarnyilk, I., Nadji, S., Brockwell, S., Webb, B., Hunter, F. and Bird, D. 2018. "Local and indigenous management of climate change risks to archaeological sites." Mitigation and Adaptation Strategies for Global Change 23: 231-255.

Causevic, A. 2017. "Facing an unpredictable threat: is NATO ideally placed to manage climate change as a non-traditional threat multiplier?" Connections 16: 59-80.

Caviedes, C.N. 2001. El Niño in History: Storming Through the Ages. Florida: University Press of Florida.

Chilton, E. \& Mason, R. 2010. A Call for a Social Science of the Past. Electronic Document, NSF. White Paper for 'SBE 2020: Future Research in the Social, Behavioral and Economic Sciences.' http://nsf.gov/sbe/sbe_2020/index.cfm. Site accessed 15 May 2020.

Chirikure, S., Ndoro, W. and Deacon, J. 2017. "Approaches and trends in African heritage management and conservation." In Managing Heritage in Africa: Who Cares? edited by W. Ndoro, S. Chirikure and J. Deacon. London: Routledge.

Claeys, F., Gourlet-Fleury, S., Picard, N., Ouédraogo, D.-Y., Tadesse, M.G., Hérault, B., Baya, F., Bénédet, F., Cornu, G. and Mortier. F. 2019. "Climate change would lead to a sharp acceleration of Central African forests dynamics by the end of the century." Environmental Research Letters 14: 044002.

Clarke, J., Khalaf, N., Iles, C., Ouweneel, B., Reimann, L., Simpson, C. and Trisos, C. forthcoming. "Loss and damage to Africa's heritage from projected sea-level rise and coastal erosion." 
Clarke, J., Brooks, N., Banning, E.B., Bar-Matthews, M., Campbell, S., Clare, L., Cremaschi, M., di Lernia, S., Drake, N., Gallinaro, M., Manning, S., Nicoll, K., Philip, G., Rosen, S., Schoop, U.-D., Tafuri, M.A., Weninger, B. and Zerboni, A. 2016. "Climatic changes and social transformations in the Near East and North Africa during the 'long' 4th millennium BC: A comparative study of environmental and archaeological evidence." Quaternary Science Reviews 136: 96-121.

Colette, A. 2007. Case Studies on Climate Change and World Heritage. Paris: UNESCO World Heritage Centre.

Collins, M., Knutti, R., Arblaster, J., Dufresne, J-L., Fichefet, T., Friedlingstein, P., Gao, X., Gutowski, W.J., Johns, T., Krinner, G., Shongwe, M., Tebaldi, C., Weaver, A.J., Wehner, M.F., Allen, M.R., Andrews, T., Beyerle, U., Bitz, C., Bony, S. and Booth, B.B. 2013. "Long-term climate change: projections, commitments and irreversibility." In Climate Change 2013 - The Physical Science Basis: Contribution of Working Group I to the Fifth Assessment Report of the Intergovernmental Panel on Climate Change, edited by T.F. Stocker, D. Qin, G.-K. Plattner, M.M.B. Tignor, S.K. Allen, J. Boschung, A. Nauels, Y. Xia, V. Bex, and P.M. Midgley, 10291136. New York: Cambridge University Press.

Cook, K.H. and Vizy, E.K. 2015. "Detection and analysis of an amplified warming of the Sahara Desert." Journal of Climate 28: 6560-6580.

Coombes, A.E., Hughes, L. and Munene, K. 2014. Managing Heritage, Making Peace: History, Identity and Memory in Contemporary Kenya. New York: I.B. Tauris.

Cormack, Z. 2016. "The promotion of pastoralist heritage and alternative 'visions' for the future of northern Kenya." Journal of Eastern African Studies 10: 548-567.

Croitoru, L., Miranda, J.J. and Sarraf, M. 2019. "The cost of coastal zone degradation in West Africa: Benin, Côte d'Ivoire, Senegal and Togo." West Africa and Coastal Areas Management Program. Washington: World Bank Group.

Cunliffe, E. 2017. "Heritage destruction: lessons from the Middle East and North Africa for post-conflict countries." In 4th International Conference on Heritage Conservation and Site Management - Catastrophe and Challenge: Cultural Heritage in Post-Conflict Recovery, edited by P. Schneider, 113-126. Cottbus: Brandenburg Cottbus University.

Daly, C. 2014. "A framework for assessing the vulnerability of archaeological sites to climate change: theory, development, and application." Conservation and Management of Archaeological Sites 16: 268-282.

Davies, J. 2008. "Turning the tide: enabling sustainable development for Africa's mobile pastoralists." Natural Resources Forum 32: 175-184

Deil, U., Culmsee, H. and Berriane. M. 2005. "Sacred groves in Morocco: a society's conservation of nature for spiritual reasons." Silva Carelica 49: 185-201.

di Lernia, S. 2005. "Incoming tourism, outgoing culture: tourism, development and cultural heritage in the Libyan Sahara." Journal of North African Studies 10: 441-457. 
di Lernia, S. 2006. "Building monuments, creating identity: cattle cult as a social response to rapid environmental changes in the Holocene Sahara." Quaternary International 151: 50-62.

Diop, A. 2018. “Tombouctou: 1'avenir des maçons traditionnels.” In World Heritage for Sustainable Development in Africa, edited by Edmond Moukala and Ishanlosen Odiaua, United Nations Educational, Scientific and Cultural Organization, 99-103. Paris: UNESCO. http://whc.unesco.org/fr/revue/82/

Djenontin, I.N.S. and Meadow, A.M. 2018. "The art of co-production of knowledge in environmental sciences and management: lessons from international practice." Environmental Management 61: 885-903

Donat, M.G., Lowry, A.L., Alexander, L.V., O'Gorman, P.A. and Maher, N. 2016. "More extreme precipitation in the world's dry and wet regions." Nature Climate Change 6: 508-513.

Dong, S. 2016. "Overview: pastoralism in the world." In Building Resilience of HumanNatural Systems of Pastoralism in the Developing World: Interdisciplinary Perspectives, edited by S. Dong, K.-A.S. Kassam, J.F. Tourrand and R.B. Boone, 1-37. New York: Springer.

Dong, B. and Sutton, R. 2015. "Dominant role of greenhouse-gas forcing in the recovery of Sahel rainfall." Nature Climate Change 5: 757-760.

Dosio, A., Jones, R.G., Jack, C., Lennard, C., Nikulin, G. and Hewitson, B. 2019. "What can we know about future precipitation in Africa? Robustness, significance and added value of projections from a large ensemble of regional climate models." Climate Dynamics 53: 58335858 .

Dossou, K.M. and Glehouenou-Dossou, B. 2007. "The vulnerability to climate change of Cotonou (Benin) the rise in sea level." Environment and Urbanization 19: 65-79.

Dželebdžić, O., Bazik, D. and Crnčević, T. 2013. "Vulnerability of natural and cultural heritage in relation to climate change - new challenge for spatial and urban planning." In 2nd International Scientific Conference: Regional Development, Spatial Planning and Strategic Governance, edited by M. Vujošević and S. Milijić, 808-822. Belgrade: Institute of Architecture and Urban \& Spatial Planning of Serbia.

Ealiwa, M.A., Taki, A.H., Howarth, A.T. and Seden, M.R., 2001. "An investigation into thermal comfort in the summer season of Ghadames, Libya." Building and Environment 36: 231-237.

Ebi, K.L. and Otmani del Barrio, M. 2017. "Lessons learned on health adaptation to climate variability and change: experiences across low- and middle-income countries." Environmental Health Perspectives 125: 065001.

Ekblom, A., Shoemaker, A., Gillson, L., Lane, P.J. and Lindholm, K.J. 2019. "Conservation through biocultural heritage - examples from sub-Saharan Africa." Land 8: 5.

Endangered Archaeology of the Middle East and North Africa (EAMENA Project) http://eamena.arch.ox.ac.uk (accessed 15 ${ }^{\text {th }}$ May 2020) 
Egloff, B. 2008. Archaeological heritage management, climate change and world heritage in the 21st century. In Heritage at risk: ICOMOS World Report 2006/2007 on monuments and sites in danger, edited by Michael Petzet and John Ziesemer. Altenburg: International Council on Monuments and Sites - E. Reinhold Verlag. 200-202.

http://www.international.icomos.org/risk/index.html Site accessed 15 May 2020

Ejiga, O., Paul, O. and Cordelia, O. 2012. "Sustainability in traditional African architecture: a springboard for sustainable urban cities." Sustainable Futures: Architecture and Urbanism in the Global South, Kampala, June 27-30.

Elgendy, K., 2011. Sustainability in the desert. Detail Green - Review of Sustainable Architecture and Energy-Efficient Refurbishment 2011/2: 16-21

Engelbrecht, F., Adegoke, J., Bopape, M.-J., Naidoo, M., Garland, R., Thatcher, M., McGregor, J., Katzfey, J., Werner, M., Ichoku, C. and Gatebe, C. 2015. "Projections of rapidly rising surface temperatures over Africa under low mitigation." Environmental Research Letters 10: 085004 .

Esteves, L.S. and Ballesteros, C. 2019. "Building an index of exposure to coastal change in eastern Africa with applications to conservation of cultural heritage." Coastal Sediments 19: 1063-1077.

Evan, A.T., Flaman, C., Gaetani M. and Guichard, F. 2016. "The past, present and future of African dust." Nature 531: 493-495.

Ezcurra, P. and Rivera-Collazo, I.C. 2018. "An assessment of the impacts of climate change on Puerto Rico's cultural heritage with a case study on sea-level rise." Journal of Cultural Heritage 32: 198-209.

Fatorić, S. and Seekamp, E. 2017. "Are cultural heritage resources threatened by climate change? A systematic literature review." Climatic Change 142: 227-254.

Food and Agriculture Organization of the United Nations (FAO). 2017. "Analysis of forests and climate change in eastern Africa." In Forests and Climate Change. Rome: FAO http://www.fao.org/3/ac836e/AC836E02.htm\#P70_3935 (accessed 15 ${ }^{\text {th }}$ May 2020)

Food and Agriculture Organization of the United Nations (FAO). 2018. Pastoralism in Africa's Drylands: Reducing Risks, Addressing Vulnerability and Enhancing Resilience. Rome: http://www.fao.org/documents/card/en/c/CA1312EN

Fleisher, J.B. and LaViolette, A. 2013. "The early Swahili trade village of Tumbe, Pemba Island, Tanzania, AD 600-950.” Antiquity 87: 1151-1168.

Fleisher, J.B. and Wynne-Jones, S. 2012. "Finding meaning in ancient Swahili spatial practices." African Archaeological Review 29: 171-207

Forsyth, G.G., Kruger, F.J. and Le Maitre, D.C. 2010. "National veldfire risk assessment: analysis of exposure of social, economic and environmental assets to veldfire hazards in 
South Africa." National Resources and the Environment CSIR Report No.0023. Stellenbosch, South Africa: Fred Kruger Consulting cc.

Fouéré, M-A. and Hughes, L. 2015. "Heritage and memory in East Africa today: a review of recent developments in cultural heritage research and memory studies." Azania: Archaeological Research in Africa 50: 542-558.

Fraser, N. 2003. "Social justice in the age of identity politics: Redistribution, recognition and participation." In Redistribution or Recognition? A Political-Philosophical Exchange, edited by N. Fraser and A. Honneth, 7-109. London: Verso.

Füssel, H.M. 2010. "How inequitable is the global distribution of responsibility, capability, and vulnerability to climate change: A comprehensive indicator-based assessment." Global Environmental Change 20: 597-611.

Giesen, M.J., Ung, A., Warke, P.A., Christgen, B., Mazel, A.D. and Graham, D.W. 2014. "Condition assessment and preservation of open-air rock art panels during environmental change." Journal of Cultural Heritage 15: 49-56.

Goussard, J-J. and Ducrocq, M. 2014. "West African coastal area: challenges and outlook." In Land/Ocean Interactions in the Coastal Zone of West and Central Africa, edited by S. Diop, J.-P. Barusseau and C. Descampes, 9-21. Cham: Springer.

Greiner, C. 2016. "Land-use change, territorial restructuring, and economies of anticipation in dryland Kenya." Journal of Eastern African Studies 10: 530-547.

Hailemariam, M. 2019. "Biodiversity storehouses and showcases of sacred natural sites for nature conservation and climate change mitigation." American Journal of Life Sciences 7: 3846.

Hall, C.M. 2015. "Heritage, heritage tourism and climate change." Journal of Heritage Tourism 11: 1-9.

Hall, K., Meiklejohn, I. and Arocena, J. 2007: "The thermal responses of rock art pigments: implications for rock art weathering in southern Africa." Geomorphology 91: 132-145.

Hall, K.,. Thorn, C. and Sumner, P. 2012. "On the persistence of "weathering." Geomorphology 149: 1-10.

Harvey, B., Cochrane, L. and Van Epp, M. 2019. "Charting knowledge co-production pathways in climate and development." Environmental Policy and Governance 29: 107-117.

Harvey, D. and Perry, J. 2015. The Future of Heritage as Climates Change: Loss, Adaptation and Creativity. London: Routledge.

Herring, R.S. 1979. "The view from Mount Otuke: migrations of the Lango Omiro." In Chronology, Migration and Drought in Interlacustrine Africa edited by J.B. Webster Dalhouse, 39-86. London: Longman University Press. 
Hœrlé, S. 2006. "Rock temperatures as an indicator of weathering processes affecting rock art." Earth Surface Processes and Landforms 31: 383-389.

Howard, A.J. 2013. "Managing global heritage in the face of future climate change: the importance of understanding geological and geomorphological processes and hazards." International Journal of Heritage Studies 19: 632-658.

Howard, A.J., Knight, D., Coulthard, T., Hudson-Edwards, K., Kossoff, D. and Malone, S. 2016. "Assessing riverine threats to heritage assets posed by future climate change through a geomorphological approach and predictive modelling in the Derwent Valley Mills WHS, UK." Journal of Cultural Heritage 19: 387-394.

Ika, L.A. and Donnelly, J. 2017. "Success conditions for international development capacity building projects." International Journal of Project Management 35: 44-63.

Israel, A.O. 2017. "Nature, the built environment and perennial flooding in Lagos, Nigeria: the 2012 flood as a case study." Urban Climate 21: 218-231.

IPCC, 2018. "Glossary." In Global Warming of $1.5^{\circ}$ C. An IPCC Special Report on the Impacts of Global Warming of $1.5^{\circ} \mathrm{C}$ above Pre-Industrial Levels and Related Global Greenhouse Gas Emission Pathways, in the Context of Strengthening the Global Response to the Threat of Climate Change, Sustainable Development, and Efforts to Eradicate Poverty, edited by V. P. V. Masson-Delmotte, P. Zhai, H.-O. Pörtner, D. Roberts, J. Skea, P.R. Shukla, A. Pirani, W. Moufouma-Okia, C. Péan, R. Pidcock, S. Connors, J.B.R. Matthews, Y. Chen, X. Zhou, M.I. Gomis, E. Lonnoy, T. Maycock, M. Tignor, and T. Waterfield. Geneva, Switzerland, pp. 541562.

Iwuagwu, B.U. and Azubuine, C.E. 2015. "Global warming versus green architecture: African experience." In Proceedings of International Conference on IT, Architecture and Mechanical Engineering (ICITAME, May 2015), 50-55. Dubai

Jamieson, D. 2010. "Climate change, responsibility, and justice." Science and Engineering Ethics 16: 431-445.

Jarvie, J., Sutarto, R., Syam, D. and Jeffery, P. 2015. "ScienceDirect lessons for Africa from urban climate change resilience building in Indonesia." Current Opinion on Environmental Sustainability 13: 19-24.

Jolly, W.M., Cochrane, M.A., Freeborn, P.H., Holden, Z.A., Brown, T.J., Williamson, G.J. and Bowman, D.M.J.S. 2015. "Climate-induced variations in global wildfire danger from 1979 to 2013." Nature Communications 6: 7537.

Jones, P.G. and Thornton, P.K. 2009. "Croppers to livestock keepers: livelihood transitions to 2050 in Africa due to climate change." Environmental Science \& Policy 12: 427-437.

Jost, C., Kyazze, F., Naab, J., Neelormi, S., Kinyangi, J., Zougmore, R., Aggarwal, P., Bhatta, G., Chaudhury, M., Tapio-Bistrom, M-L., Nelson, S. and Kristjanson, P. 2016. "Understanding gender dimensions of agriculture and climate change in smallholder farming communities." Climate and Development 8: 133-144. 
Jousse, H. 2006. "What is the impact of Holocene climatic changes on human societies? Analysis of West African Neolithic populations dietary customs." Quaternary International 151: 63-73.

Joy, C.L. 2007: "Enchanting town of mud: Djenné, a World Heritage site in Mali." In Reclaiming Heritage: Alternative Imaginaries of Memory in West Africa, edited by F. de Jong and M. Rowlands, 145-160. London: Routledge.

Joy, C.L. 2016. The Politics of Heritage Management in Mali: From UNESCO to Djenné. London: Routledge.

Kagunyu, A., Wandibba, S. and Wanjohi, J.G. 2016. "The use of indigenous climate forecasting methods by the pastoralists of northern Kenya." Pastoralism 6: 7.

Kavana, P.Y., Mahonge, C.P., Sangeda, A.Z., Mtengeti, E.J., Fyumagwa, R., Nindi, S., Graae, B.J., Nielsen, M.R., John, B., Keyyu, J., Speed, J., Smith, S., Hassan, S., Ntalwila, J. and Ilomo, O. 2017. "Panorama of agro-pastoralism in western Serengeti: A review and synthesis." Livestock Research for Rural Development 29: 10. http://www.lrrd.org/lrrd29/10/pyka29191.html Site accessed 15 May 2020.

Keenan, J. 2005. "Looting the Sahara: the material, intellectual and social implications of the destruction of cultural heritage briefing." Journal of North African Studies 10: 471-489.

Keitumetse, S.O. 2016. African Cultural Heritage Conservation and Management: Theory and Practice from Southern Africa. Switzerland: Springer.

Kelman, I. Haugen, A. and Mattsson, J. 2011. "Preparations for climate change's influences on cultural heritage." International Journal of Climate Change Strategies and Management 3: $386-401$.

Kendon, E.J., Stratton, R.A., Tucker, S., Marsham, J.H., Berthou, S., Rowell, D.P. and Senior, C.A. 2019. "Enhanced future changes in wet and dry extremes over Africa at convectionpermitting scale." Nature Communications 10: 1794.

Khalil, H.A.E.E., Ibrahim, A., Elgendy, N. and Makhlouf, N. 2018. Could/should improving the urban climate in informal areas of fast-growing cities be an integral part of upgrading processes? Cairo case. Urban Climate 24: 63-79.

Klutse, N.A.B., Ajayi, V.O., Gbobaniyi, E.O., Egbebiyi, T.S., Kouadio, K., Nkrumah, F., Quagraine, K.A., Olusegun, C., Diasso, U., Abiodun, B.J., Lawal, K., Nikulin, G., Lennard, C. and Dosio, A. 2018. "Potential impact of $1.5^{\circ} \mathrm{C}$ and $2^{\circ} \mathrm{C}$ global warming on consecutive dry and wet days over West Africa." Environmental Research Letters 13: 055013.

Korf, B., Hagmann, T. and Emmenegger, R. 2015. "Re-spacing African drylands: territorialization, sedentarization and indigenous commodification in the Ethiopian pastoral frontier." Journal of Peasant Studies 42: 881-901.

Krätli, S., Huelsebusch, C., Brooks, S. Kaufmann, B. 2013. "Pastoralism: a critical asset for food security under global climate change." Animal Frontiers 3: 42-50. 
Kulp, S.A. and Strauss, B.H. 2019. "New elevation data triple estimates of global vulnerability to sea-level rise and coastal flooding." Nature Communications 10: 4844.

Kundzewicz, Z.W., Kanae, S., Seneviratne, S.I., Handmer, J., Nicholls, N., Peduzzi, P., Mechler, R., Bouwer, L.M., Arnell, N., Mach, K., Muir-Wood, R., Brakenridge, G.R., Kron, W., Benito, G., Honda, Y., Takahashi, K. and Sherstyukov, B. 2014. "Flood risk and climate change: global and regional perspectives." Hydrological Sciences Journal 59: 1-28.

Lane, C.R. 1997. Custodians of the Commons: Pastoral Land Tenure in East and West Africa. London: Earthscan.

Lehsten, V., Tansey, K., Balzter, H., Thonicke, K., Spessa, A., Weber, U., Smith, B. and Arneth, A. 2009. "Estimating carbon emissions from African wildfires." Biogeosciences 6: 349-360.

Lindholm, K-J. and Ekblom, A. 2019 "A framework for exploring and managing biocultural heritage." Anthropocene 25: 100195.

Liu, Y., Stanturf, J. and Goodrick, S. 2010. "Trends in global wildfire potential in a changing climate." Forest Ecology and Management 259: 685-697.

Locke, J.T. 2009. "Climate change-induced migration in the Pacific region: sudden crisis and long-term developments 1." The Geographical Journal 175: 171-180.

Lostal, M. Hausler, K. and Bongard, P. 2017. "Armed non-state actors and cultural heritage in armed conflict." International Journal of Cultural Property 24: 407-427.

Mahoo, H., Mbungu, W., Yonah, I., Radeny, M.A., Kimeli, P. and Kinyangi, J. 2015. Integrating Indigenous Knowledge with Scientific Seasonal forecasts for Climate Risk Management in Lushoto District in Tanzania. Copenhagen: CGIAR Research Program on Climate Change, Agriculture and Food Security.

Manning, K. and Timpson, A. 2014. "The demographic response to Holocene climate change in the Sahara." Quaternary Science Reviews 101: 28-35.

Manetsi, T. 2011. "Safeguarding intangible heritage in South Africa: a critique of the Draft National Policy on Living Heritage." International Journal of Intangible Heritage 6: 57-69.

Martinez-Alier, J., Temper, L., Del Bene, D. and Scheidel, A. 2016. "Is there a global environmental justice movement?” Journal of Peasant Studies 43: 731-755.

Mashizha, T.M., Monga, M. and Dzvimbo, M.A. 2017 "Improving livelihoods of resettled farmers through development of a knowledge base on climate change in Mhondoro - Ngezi District, Zimbabwe." International Journal of Sustainable Development Research 3: 18-26.

Maus, S. 2014. "Hand in hand against climate change: cultural human rights and the protection of cultural heritage." Cambridge Review of International Affairs 27: 699-716.

McIntosh, S.K. 1995. Excavations at Jenné-Jeno, Hambarketolo, and Kaniana (Inland Niger Delta, Mali), the 1981 Season. San Francisco: University of California Press. 
Meiklejohn, K.I., Hall, K. and Davis, J.K. 2009. "Weathering of rock art at two sites in the KwaZulu-Natal Drakensberg, southern Africa." Journal of Archaeological Science 36: 973979.

Mitchell, P.J. 2008. "Practising archaeology at a time of climatic catastrophe." Antiquity 82: $1093-1103$.

Mol, L. and Viles, H.A. 2010. "Geoelectric investigations into sandstone moisture regimes: Implications for rock weathering and the deterioration of San rock art in the Golden Gate Reserve, South Africa." Geomorphology 118: 280-287.

Msuya, T.S. and Kideghesho, J.R. 2009. "The role of traditional management practices in enhancing sustainable use and conservation of medicinal plants in West Usambara Mountains, Tanzania." Tropical Conservation Science 2: 88-105.

Nara, Y., Morimoto, K., Yoneda, T., Hiroyoshi N. and Kaneko, K. 2011. "Effects of humidity and temperature on subcritical crack growth in sandstone." International Journal of Solids and Structures 48: 1130-1140.

Ndoro, W. 2015. "World Heritage Sites in Africa: what are the benefits of nomination and inscription?". In A Companion to Heritage Studies, edited by W. Logan, M. Nic Craith and U. Kockel, 392-409. New Jersey: John Wiley and Sons.

Nganso, T.B., Kyerematen, R. and Obeng-Ofori. D. 2012. "Review of biodiversity in sacred groves in Ghana and implications on conservation." Current Trends in Ecology 3: 1-10.

Ngaruiya, G.W. and Muithui, L. W. 2016. Deconstructing a Pastoralists' Network to Evaluate Climate Adaptation in the Sector: A Case Study of Narok, Kenya. Small Grants Programme Working Paper, PRISE (Pathways to resilience in semi-arid economies). Collaborative Adaptation Research Initiative in Africa and Asia (CARIAA). London: Overseas Development Institute.

Nhamo, A. 2018. "Burning images: a critical review of rock art conservation in Zimbabwe." Conservation and Management of Archaeological Sites 20: 58-75.

Nicu, I.C. 2017. "Natural hazards - a threat for immovable cultural heritage. A review." International Journal of Conservation Science 8: 376-388.

Nordic Development Fund. http://www.ndf.fi/project/west-africa-coastal-area-erosion-andadaptation-ndf-c77. Site accessed 15 May 2020.

Nordic Development Fund. http://www.ndf.fi/news/west-africa-coastal-erosion-projectlaunched-togo

Nurse, L.A., Mclean, R.F., Agard, J., Briguglio, L.P., Duvat-Magnan, V., Pelesikoti, N., Tompkins, E. and Webb, A. 2014. "Small islands." In Climate Change 2014: Impacts, Adaptation, and Vulnerability. Part B: Regional Aspects. Contribution of Working Group II to the Fifth Assessment Report of the Intergovernmental Panel on Climate Change, edited by V.R. Barros, C.B. Field, D.J. Dokken, M.D. Mastrandrea, K.J. Mach, T.E. Bilir, M. Chatterjee, K.L. 
Ebi, Y.O. Estrada, R.C. Genova, B. Girma, E.S. Kissel, A.N. Levy, S. MacCracken, P.R. Mastrandrea, and L.L. White, 1613-1654. Cambridge: Cambridge University Press.

Oba, G. 2014. Climate Change Adaptation in Africa: An Historical Ecology. London: Routledge.

O'Brien, G., O'Keefe, P., Jayawickrama, J. and Jigyasu. R. 2015. "Developing a model for building resilience to climate risks for cultural heritage." Journal of Cultural Heritage Management and Sustainable Development 5: 99-114.

O'Gorman, P.A. 2012. "Sensitivity of tropical precipitation extremes to climate change." Nature Geoscience 5: 697-700.

O'Gorman, P.A. 2015. "Precipitation extremes under climate change." Current Climate Change Reports 1: 49-59.

Ogundiran, A. and Ogunfolakan, A. 2017. "Colonial modernity, rituals and feasting in Odùduwà Grove, Ilé-Ifẹ̀ (Nigeria).” Journal of African Archaeology 15: 77-103.

Okereke, C. and Coventry, P. 2016. "Climate justice and the international regime: before, during, and after Paris: climate justice and the international regime." Wiley Interdisciplinary Reviews: Climate Change 7: 834-851.

Owusu, K. and Oteng-Ababio, M. 2011: "The vulnerable state of the Ghana coast: the case of Faana-Bortianor.” Jàmbá: Journal of Disaster Risk Studies 3: 429-442.

Pacific Climate Change Portal. International Climate Change Adaptation Initiative (ICCAI) https://www.pacificclimatechange.net Site accessed 20 January 2020.

Panthou, G., Vischel, T. and Lebel, T. 2014. "Recent trends in the regime of extreme rainfall in the Central Sahel: recent trends of extreme rainfall in the West African Sahel." International Journal of Climatology 34: 3998-4006.

Papalexiou, S.M., AghaKouchak, A., Trenberth, K.E. and Foufoula-Georgiou, E. 2018. "Global, regional, and megacity trends in the highest temperature of the year: diagnostics and evidence for accelerating trends." Earth's Future 6: 71-79.

Parcak, S., Mumford G. and Childs, C. 2017. "Using open access satellite data alongside ground based remote sensing: an assessment, with case studies from Egypt's Delta." Geosciences 7: 94.

Park Williams, A., Abatzoglou, J.T., Gershunov, A., Guzman-Morales, J., Bishop, D.A., Balch, J.K. and Lettenmaier, D.P. 2019. "Observed impacts of anthropogenic climate change on wildfire in California." Earth's Future 7: 892-910.

Parthasarathy, N. and Naveen Babu, K. 2019. "Sacred groves: potential for biodiversity and bioresource management." In Life on Land, edited by W.L. Filho, A.M. Azul, L. Brandli, P.G. Özuyar and T. Wall, 1-16. Cham: Springer. 
Pavlova, I., Makarigakis, A., Depret, T. and Jomelli, V. 2017. "Global overview of the geological hazard exposure and disaster risk awareness at world heritage sites." Journal of Cultural Heritage 28: 151-157.

Perry, J. 2015. "Climate change adaptation in the world's best places: a wicked problem in need of immediate attention." Landscape and Urban Planning 133: 1-11.

Phillips, H. 2015. "The capacity to adapt to climate change at heritage sites - the development of a conceptual framework." Environmental Science and Policy 47: 118-125.

Pollard, E. 2009. "Settlement adaptation to a changing coastline: archaeological evidence from Tanzania, during the first and second millennia AD." Journal of Island and Coastal Archaeology 4: 82-107.

Pollard, E. 2012. "Present and past threats and response on the east coast of Africa: an archaeological perspective." Journal of Coastal Conservation 16: 143-158.

Popay, J. Roberts, H. Sowden, A. Petticrew, M. Arai, L. Rodgers, M. Britten, N. Roen, K. and Duffy, S. 2004. Guidance on the Conduct of Narrative Synthesis in Systematic Reviews. Draft Report from ESRC Methods Programme. Lancaster: Institute for Health Research, University of Lancaster.

Radimilahy, C.M. and Crossland, Z. 2015. "Situating Madagascar: Indian Ocean dynamics and archaeological histories." Azania: Archaeological Research in Africa 50: 495-518.

Reimann, L., Vafeidis, A.T., Brown, S., Hinkel, J. and Tol, R.S. 2018. "Mediterranean UNESCO World Heritage at risk from coastal flooding and erosion due to sea-level rise." Nature Communications 9: 1-11.

Reyes-García, V., Fernández-Llamazares, Á., Guèze, M., Garcés, A., Mallo, M., Vila-VilaGómez, M. and Vilaseca, M. 2016. "Local indicators of climate change: the potential contribution of local knowledge to climate research." Wiley Interdisciplinary Reviews: Climate Change 7: 109-124.

Robinson, M. and Shine, T. 2018. “Achieving a climate justice pathway to $1.5^{\circ} \mathrm{C}$." Nature Climate Change 8: 564-569.

Roe, E., Huntsinger, L. and Labnow, K. 1998. "High reliability pastoralism.” Journal of Arid Environments 39: 39-55.

Rowlands, M. and De Jong, F. 2007. "Reconsidering heritage and memory." In Reclaiming Heritage: Alternative Imaginaries of Memory in West Africa, edited by F. de Jong and M. Rowlands, 13-29. Walnut Creek: Left Coast Press.

Sabbioni, C., Cassar, M., Brimblecombe, P. and Lefevre, R.A. 2008. Vulnerability of Cultural Heritage to Climate Change. Strasbourg: Council of Europe. 
Sawchuk, E.A., Goldstein, S.T., Grillo, K.M. and Hildebrand, E.A. 2018. "Cemeteries on a moving frontier: mortuary practices and the spread of pastoralism from the Sahara into eastern Africa." Journal of Anthropological Archaeology 51: 187-205.

Schlosberg, D. and Collins, L.B. 2014. "From environmental to climate justice: climate change and the discourse of environmental justice." Wiley Interdisciplinary Reviews: Climate Change 5: 359-374.

Schneider, L. 2006. "The Maasai's new nlothes: a developmentalist modernity and Its exclusions." Africa Today 53: 101-131.

Sheridan, M.J. and Nyamweru, C. (eds). 2007. African Sacred Groves: Ecological Dynamics and Social Change. Athens: Ohio University Press

Shirvani Dastgerdi, A., Sargolini, M. and Pierantoni, I. 2019. "Climate change challenges to existing cultural heritage policy." Sustainability 11: 5227.

Sivili, S., 2002. "A historical background: mortuary archaeology in the Sahara between colonialism and modern research." In Sand, Stones and Bones: The Archaeology of Death in the Wadi Tannezzuft Valley (5000-2000 BP). Edited by S. di Lernia and G. Manzi, 17-24. Firenze: All'Insegna del Giglio.

Skinner, C.B. and Diffenbaugh, N.S. 2014. "Projected changes in African easterly wave intensity and track in response to greenhouse forcing." Proceedings of the National Academy of Sciences of the United States of America 111: 6882-6887.

Smith, A.B. 1992. Origins and spread of pastoralism in Africa. Annual Review of Anthropology 21: 125-141.

Smith, B.W. 2013. "Rock art research in Africa". In The Oxford Handbook of African Archaeology, edited by P.J. Mitchell and P.J. Lane, 145-162. Oxford: Oxford University Press.

Smith, B.W. 2014. "Chongoni rock art area." Oriental Art 50: 6-24.

Sperling, C.H.B. and Cooke, R.U. 1985. "Laboratory simulation of rock weathering by salt crystallization and hydration processes in hot, arid environments." Earth Surface Processes and Landforms 10: 541-555.

Stanley, J.D. and Clemente, P.L. 2017. "Increased land subsidence and sea-level rise are submerging Egypt's Nile Delta coastal margin.” GSA Today 27: 4-11.

Stewart, J. and Strathern, A. 2003. Landscape, Memory and History Anthropological Perspectives. London: Pluto Press

Taçon, P. 2019. The Aftermath of Fire Damage to Important Rock Art at the Baloon Cave Tourist Destination, Carnarvon Gorge, Queensland, Australia. http://www.bradshawfoundation.com/rockartnetwork/baloon_cave.php Site accessed 24 January 2020. 
Tadross, M., Davis, C., Engelbrecht, F., Joubert, A. and Archer, E.R. 2011. "Regional scenarios of future climate change over southern Africa." In Climate Risk and Vulnerability: A Handbook for Southern Africa, edited by C. Davis, 28-50. Pretoria: Council for Scientific and Industrial Research.

Tamou, C., De Boer, I.J.M., Ripoll-Bosch, R. and Oosting, S. J. 2018. "Traditional ecological knowledge underlying herding decisions of pastoralists.” Animal 12: 831-843.

Tilley, C. 1994. A Phenomenology of Landscape: Places Paths and Monuments. London: Bergh.

Taylor, C.M., Belušić, D., Guichard, F., Parker, D.J., Vischel, T., Bock, O., Harris, P.P., Janicot, S., Klein, C. and Panthou, G. 2017. "Frequency of extreme Sahelian storms tripled since 1982 in satellite observations." Nature 544: 475-478.

Turkington, A.V. and Paradise, T.R. 2005. "Sandstone weathering: a century of research and innovation." Geomorphology 67: 229-253.

Turner, M. 1993. "Overstocking the range: a critical analysis of the environmental science of Sahelian pastoralism.” Economic Geography 69: 402-421.

UNESCO 2018. World Heritage for Sustainable Development in Africa. Paris: UNESCO.

Global Alliance for Buildings and Construction, UNEP and IEA 2019. 2019 Global Status report for Buildings and Construction: Towards a Zero-Emission, Efficient, and Resilient Buildings and Construction Sector. Global Status Report 2019. Nairobi: UNEP.

United Nations Environment Programme 2019. The Emissions Gap Report 2019. https://www.unenvironment.org/resources/emissions-gap-report-2019 Site accessed 23 January 2020.

Viles, H.A. and Cutler, N.A. 2012. "Global environmental change and the biology of heritage structures." Global Change Biology 18: 2406-2418.

Vousdoukas, M.I., Ranasinghe, R., Mentaschi, L., Plomaritis, T.A., Athanasiou, P., Luijendijk, A. and Feyen, L. 2020. "Sandy coastlines under threat of erosion." Nature Climate Change 10: 260-263.

Wamsler, C. 2017. "Stakeholder involvement in strategic adaptation planning: Transdisciplinarity and co-production at stake?" Environmental Science \& Policy 75: 148-157.

Wangui, E. E. 2014. "Gender, livelihoods and the construction of climate change among Masai pastoralists." In Global Perspectives on Gender and Space: Engaging Feminism and Development, edited by A.M. Oberhauser and I. Johnston-Anumonwo, 163-180. London: Routledge.

Wangui, E. 2018. "Adaptation to current and future climate in pastoral communities across Africa." Oxford Research Encyclopedia of Climate Science. https://oxfordre.com/climatescience/view/10.1093/acrefore/9780190228620.001.0001/acrefor e-9780190228620-e-604 Site accessed 15 May 2020. 
Wangui, E.E. and Smucker, T. A. 2017. "Gendered opportunities and constraints to scaling up: a case study of spontaneous adaptation in a pastoralist community in Mwanga District, Tanzania" Climate and Development 10: 369-376.

Warke, P.A., Smith, B.J. and Magee, R.W. 1996. "Thermal response characteristics of stone: implications for weathering of soiled surfaces in urban environments." Earth Surface Processes and Landforms 21: 295-306.

Westra, S., Fowler, H.J., Evans, J.P., Alexander, L.V., Berg, P., Johnson, F., Kendon, E.J., Lenderink, G. and Roberts, N.M. 2014. "Future changes to the intensity and frequency of shortduration extreme rainfall: future intensity of sub-daily rainfall" Reviews of Geophysics 52: $522-555$.

White, A.F. and Buss, H.L. 2014. "Natural weathering rates of silicate minerals." Treatise on Geochemistry: 115-155.

Winthrop, K., n.d. Bare Bones Guide to Fire Effects on Cultural Resources. US Bureau of Land Management. Accessed on $15^{\text {th }}$ January 2020 via US National Park Service, US Department of the Interior:

https://www.nps.gov/archeology/npsGuide/fire/docs/8\%20Bare\%20Bones\%20Guide\%20to\% 20Fire\%20Effects\%20on\%20CR-BLM(Winthrop).pdf.

Woosnam, K.M., Kayode, D. A. and Maruyama, N. 2016. "Solidarity at the Osun Osogbo Sacred Grove - a UNESCO World Heritage site". Tourism Planning and Development 13: 274-291.

Yin, J. Gentine, P. Zhou, S. Sullivan, S.C. Wang, R. Zhang, Y. and Guo, S. 2018. "Large increase in global storm runoff extremes driven by climate and anthropogenic changes." Nature Communications 9: 4389.

Zewde, B. 1976. "A historical outline of famine in Ethiopia." In Rehab: Drought and Famine in Ethiopia, edited by A.M. Husseine, 52-58. London: International Africa Institute.

Zhang, Y., Block, P., Hammond, M. and King, A. 2015. "Ethiopia's Grand Renaissance Dam: implications for downstream riparian countries." Journal of Water Resources Planning and Management 141: 05015002. 